Lech Wyszczelski ${ }^{1}$

\title{
Tadeusz Bodio, Joanna Marszałek-Kawa (red.), Z badań nad historią i współczesnością Rosji, Azji Centralnej i Kaukazu, Wydawnictwo Adam Marszałek, Toruń 2020, ss. 270.
}

Joanna Marszałek-Kawa, Krzysztof Zamasz (red.), Chiny z perspektywy XXI wieku, Wydawnictwo Adam Marszałek, Toruń 2020, ss. 220. Joanna Marszałek-Kawa, Grzegorz Kinelski (red.), Współczesne bezpieczeństwo regionu Azji i Pacyfiku. Wybrane problemy, Toruń 2020, Wydawnictwo Adam Marszałek, ss. 244.

Już recenzując trzy publikacje z serii „Biblioteka Azji i Pacyfiku” w 2019 r. starałem się przybliżyć genezę jej powstania, oraz rolę Wydawnictwa Adam Marszałek w popularyzowaniu problemów przede wszystkim dotyczących Chińskiej Republiki Ludowej, szerzej państw Azji jako kontynentu, rejonu Pacyfiku, także po części Federacji Rosyjskiej z uwagi na jej rolę jako państwa obszarowo w przeważającej części przynależnego do kontynentu azjatyckiego.

Tyle pewnych uwag ogólnych wprowadzających do zasadniczej części niniejszej recenzji i tym razem bardziej próby omówienia zawartości poszczególnych tomów. Uznałem, iż w tym opracowaniu zapoznam Czytel-

1 Profesor emerytowany, Akademia Obrony Narodowej w Warszawie, Uniwersytet Przyrodniczo-Humanistyczny w Siedlcach, lech.wyszczelski1942@gmail.com, https:// orcid.org/0000-0003-2063-4281. 
ników z zawartością trzech wymienionych w tytule tej recenzji książek, które w „Biblioteczce Azji i Pacyfiku” ukazały się w 2020 r.

Jako pierwsza analiza dotyczy publikacji pt. Z badań nad historia i współczesnością Rosji, Azji Centralnej i Kaukazu. Przedstawiona zostanie zawartość i treści opracowania oraz wniesienie pewnych uwag recenzyjnych do niej się odnoszących. Składa się ona ze wstępu oraz podzielona została na trzy części: Federacja Rosyjska, Azja Centralna oraz Kaukaz. Część pierwsza składa się z następujących artykułów: Jacek Sobczak „Wpływ Rosyjskiej Cerkwi Prawosławnej na politykę międzynarodową Federacji Rosyjskiej”; Katarzyna Chałubińska-Jentkiewicz pt. „Prawosławie a media - przypadek regulacji rosyjskich"; Grzegorz Bonusiak pt. „Czukcze w Federacji Rosyjskiej”. Część druga to publikacje: Tadeusza Bodio i Andrzeja Wierzbickiego pt. „Badania transformacji ustrojowej w państwach Azji Centralnej”; Jakuba Potulskiego pt. „One Road One Belt Initiative a amerykańska strategia wobec Azji Środkowej”; Krystyny Gomółka pt. „Kobiety w polityce i władzach Kazachstanu” oraz Lindy Masalskiej pt. „Społeczne i kulturalne aspekty statusu języka rosyjskiego w państwach Azji Centralnej". Część trzecia zawiera artykuły Andrzeja Furiera pt. „Polska aktywność polityczna i wojskowa na Kaukazie w XIX wieku” oraz Grzegorza Piwnickiego pt. „Polscy żołnierze armii carskiej w dziewiętnastowiecznej Armenii".

Pragnę zwrócić uwagę na wartość i aktualną przydatność publikacji prof. Jacka Sobczaka, a to z uwagi na próbę odbudowy mocarstwowej pozycji Federacji Rosyjskiej i wykorzystywanie między innymi przez prezydenta Władimira Putina do tego celu „polityki historycznej”. Ciekawe są rozważania wobec tego jak w tym obszarze wykorzystywane są przez wymienionego relacje z Kościołem Prawosławnym. W tym wypadku cel państwa i zwierzchników wymienionej religii jest ze wszech miar wspólny. Otóż w 2007 r., kiedy doszło - duży wpływ władz państwowych Federacji Rosyjskiej - do zjednoczenia Cerkwi Patriarchatu Moskiewskiego z Rosyjską Prawosławną Cerkwią za Granicą i kiedy zwierzchnik rosyjskiego prawosławia Cyryl stwierdził, że kierowana przez niego Cerkiew „zobowiązana jest do podjęcia wszelkich działań mających na celu zabezpieczenie interesów Rosji na arenie międzynarodowej oraz "umacniania tradycyjnych wartości«, z których najważniejszą jest idea "Wielkiej Rosji«" (s. 33) ta współpraca w pełni nastąpiła. Przyjmuje się, że 
postawa hierarchów Patriarchatu Moskiewskiego współgrała z wypracowaną i zaakceptowaną przez Putina doktryną polityczną „rosyjskiego świata" w której Federacja Rosyjska uznana została za wspólnotę kulturową wszystkich państw, w których dominuje język rosyjski (odnosi się to m.in. do Federacji Rosyjskiej, Białorusi, Ukrainy, Kazachstanu i Mołdawii), s. 34.

W powyższych okolicznościach z inspiracji prezydenta Putina ponownie zwrócono się i to na początku XXI w. ku idei „bizantyzmu”, tym razem w postaci „nowobizantyzmu”. Współczesne jego wydanie odwołuje się nie tylko do doświadczenia Cesarstwa Bizantyjskiego, ale też do dokonań Imperium Rosyjskiego jako kontynuatora tej idei. Ponownie wyeksponowano rolę Cerkwi prawosławnej jako ideowego jej nośnika. Odnosi się to do wiodącej rangi nadanej Patriarchatowi Moskiewskiemu z przyznaniem mu kierowniczej roli realizowanej do wszystkich wyznawców prawosławia. Jest jednak opór przeciwko takiej podległości części innych patriarchatów. I tak w 2018 r. uwolniła się od takiej zwierzchności Cerkiew Kijowska.

Prof. Sobczak w interesujący sposób przestawił zarówno wpływ Rosyjskiej Cerkwi Prawosławnej na realizację przez Wielkie Księstwo Moskiewskie, następnie Imperium Rosyjskie, jak także po śmierci Stalina, a w szczególności współcześnie za rządów prezydenta Putina, na politykę zagraniczną. Spuentować to można stwierdzeniem, że prawosławie i jej rosyjscy zwierzchnicy starali się zawsze wspierać politykę zagraniczną swego państwa, w tym poprzez szerzeni idei budowy wielkiej Rusi, współcześnie powrotu do roli supermocarstwa.

Koresponduje po części z ciekawymi wywodami prof. Sobczaka referat Katarzyny Chałubińskiej-Jentkiewicz, z Akademii Sztuki Wojennej w Warszawie, o regulacjach rosyjskich na linii prawosławie-media. Prawosławie uznane zostało za religię państwową ale mimo tego przepisy prawne są przeciwne ewangelizacji, bowiem „działalność misyjna nie może być prowadzona w imieniu zagranicznej organizacji religijnej” (s. 59). Ponadto w obowiązujących postanowieniach prawnych znajduje się bardzo dużo ograniczeń dla prowadzenia pracy misyjnej. Wszystko to wynika z systemu powiązania państwa z prawosławiem jako religią państwową. Stąd wolne media postrzegane są jako zagrożenie nie tylko dla tej religii, ale i polityki informacyjnej tego państwa. 
Do pozostałych referatów nie będą się szczegółowiej ustosunkowywał poza ogólnym stwierdzeniem, że mają charakter opracowań podejmujących dość wąską problematykę. Mogą polskiego Czytelnika zainteresować dwie ostatnie pozycje dotyczące polskich tradycji wojskowych XIX w. na Kaukazie i Armenii. Tyle moich uwag do tej publikacji.

Drugi z recenzowanych tomów prezentuje spojrzenie na Chiny z perspektywy obecnego wieku. Tradycyjnie rozpoczyna się od ciekawego wstępu napisanego przez redaktorów naukowych tego opracowania prof. Joannę Marszałek-Kawę i Krzysztofa Zamasza. Natomiast w kolejności umieszczone zostały przygotowane autorskie wystąpienia. Oto one. Marcin Przech przygotował referat pt. „Główne kierunki polityki zagranicznej Chińskiej Republiki Ludowej w świetle konferencji prasowej ministra spraw zagranicznych ChRL Wang Yi w dniu 8 marca $1918 \mathrm{r}$. Kontynuacja i nowe akcenty"; Mateusz Wróblewski jest autorem opracowania pt. „Strategiczne partnerstwo chińsko-rosyjskie w sektorze energetycznym 2014-2019”; Renata Podgórska pt. „Polityka Chińskiej Republiki Ludowej wobec Bałkanów Zachodnich"; Wioleta Gierszewska pt. „Obecność Chin w Rwandzie w sferze polityczno-gospodarczej”; Marcin Czyżewski pt. „Kwestia Tybetu w stosunkach czesko-chińskich”; Maria Magdalena Sztuka pt. „Chińska decyzja administracyjna o ukaraniu - cechy językowe”; Iwona Grodź pt. „Zhang Yimou. Między prawdą a iluzją”, Yonyou Lu pt. „Tradycyjne chińskie symbole w sztuce współczesnej”; Katarzyna Matuszczyk-Lu pt. „Między tradycją a innowacją - chińska architektura współczesna”; Helena Jadwiga Błazińska pt. „System nauczania w dawnych Chinach”; Anna Gryszkiewicz pt. „Symbolika tańca w kole plemienia Amis podczas Święta Żniw w Yuli na Tajwanie - ujęcie postkolonialne”; Kornel Bielawski pt. „Indonezja po wyborach powszechnych w 2019 r.: w stronę rozwiązań nieliberalnych?" oraz Katarzyna Sopolińska pt. „Wybory parlamentarne w Bhotanie w latach 2008-2018”.

Uznając ważność zmian zachodzących w ostatnich latach w chińskiej polityce zagranicznej, a jedną z nich są nowe wyzwania przed nią stawiane przedstawione w opracowaniu Marcina Przecha, który zaprezentował to w przywołanym wystąpieniu 8 marca 1918 r. ówczesnego szefa dyplomacji tego państwa koniecznym wydaje się poprzedzenie tego przedstawieniem przyczyn takowego postępowania. Stąd pozwałam sobie na wprowadzenie do tego tematu. 
Nie ulega wątpliwości, że ojcem pomysłu wprowadzenia ChRL do walki o odgrywanie kluczowej roli w świecie były reformy zainicjowane przez Deng Xiaopinga. Dotyczyły wielu obszarów funkcjonowania tego państwa. Najczęściej wiązane jest to z „cudem” gospodarczym powodującym, iż państwo to stało się już drugą potęgą gospodarczą świata z perspektywą wyprzedzenia nawet USA. W tym wypadku zwrócę uwagę na jego wytyczne stawiane przed polityką zagraniczną ChRL.

Twórca chińskiego cudu gospodarczego, odchodząc na polityczną emeryturę, przypomniał następcom starożytne maksymy. Jedna z nich brzmiała: „Nie podnoście głów!”. „Nie rośćcie sobie pretensji do przywództwa, bo za wcześnie na to. Jeszcze sprowokujecie silniejszych i wszystkie wyrzeczenia chińskiej transformacji pójdą na marne". Jeszcze inna "Chiny muszą ukrywać swoją siłę i czekać na swój czas”. Zaobserwować można aktualne dużą zmianę w jej polityce zagranicznej. Do końca pierwszej dekady XXI w. była to świadoma taktyka, ścisłe podążająca za politycznym testamentem Deng Xiaopinga. Zmiana nastąpiła od 2012 r. po przejęciu przywództwa tym krajem przez Xi Jinpinga. Określił on ustrój ChRL jako „socjalizm nowej ery z chińską specyfiką”. Doprowadzono do ograniczenia autonomii Hongkongu. ChRL w zamian za długi zabrała na 99 lat Sri Lance port Hambantota, nałożyła nieoficjalne sankcje na Koreę Południową jako karę za zacieśnienie współpracy z USA i sprowokowała starcia graniczne z Indiami w Himalajach, aktualnie sankcjami objęto Australię za domaganie się międzynarodowego śledztwa w sprawie przyczyn wybuchu pandemii spowodowanej przez wirusy COVID-19 zapoczątkowanej w ChRL. Nie byłoby to możliwe bez sukcesów na polu ekonomicznym, które przełożyły się także na ogromny wzrost potencjału Chińskiej Armii Ludowej-Wyzwoleńczej oraz związane z tym zmiany w strategii polityczno-militarnej tego państwa. Mając duże osiągnięcia w przygotowaniach Chińskiej Armii Ludowo-Wyzwoleńczej do nowoczesnej wojny oraz szczególnie duże w ekonomicznym rozwoju państwa kierownictwo polityczne ChRL postanowiło oficjalnie głosić swe aspiracje mocarstwowe o globalnym charakterze. Czynione było to stopniowo.

Chińscy liderzy co prawda jeszcze oficjalnie próbowali wielokrotnie umniejszać znaczenie ryzyka konfrontacji globalnej mocarstw. Prezydent Xi Jinping w 2015 r. w czasie wizyty w USA stwierdził, że taki konflikt 
mocarstw nie jest nieunikniony tak długo, jak długo poszczególne strony wystrzegają się błędów w kalkulacjach strategicznych. W praktyce stawiał on jednak na zbrojenia swego kraju. Obiecał, jeszcze oficjalnie tego nie głosząc, że uczyni z Chin potęgę militarną. W dyplomacji tego kraju rozpoczął się jednak w drugiej połowie drugiej dekady XXI w. etap jawnego krytykowania państw zachodu, z USA włącznie, za ich ciągoty do dominacji w świecie.

Chiny, zdaniem Xi Jinpinga, muszą mówić głosem, w którym nie ma miejsca na słabość. Tylko tak przetrwają „nowy Długi Marsz”, czyli rywalizację z USA. Inaczej skończą jak ZSRR, który - według Xi Jinpinga - upadł nie z powodu bankructwa ekonomicznego i presji Zachodu, ale $z$ upadku wiary $w$ komunizm². Jest to jednoznaczna zapowiedź otwartego przystąpienia tego mocarstwa do rywalizacji o światowe przywództwo. To nie były tylko deklaracje polityczne.

Jednocześnie Pekin dokonał zmiany w priorytetach swej dyplomacji. Porzucona została strategia nieingerencji na rzecz bardziej interwencjonalistycznego podejścia. Szef resortu spraw zagranicznych tego państwa Wang Yi już w 2018 r. zapowiedział prowadzenie przez jego kraj bardziej aktywnej polityki zagranicznej. Znalazło się to właśnie w opisywanym przez Marcina Przecha recenzowanym opracowaniu.

Dodając nieco do przywoływanej problematyki wydaje się, że dostrzegać należy coraz bardziej otwarte głoszenie przez chińską dyplomację aspiracji mocarstwowych oraz podejmowanie zdecydowanej odpowiedzi na krytykę ze strony USA. Zauważyć należy też i to, że po zmianie w styczniu 2021 r. ekipy władzy w USA i próbach dyplomacji tego państwa wskazywania na ChRL jako potencjalnie największe zagrożenia dla Waszyngtonu reakcja Pekinu staje się coraz bardziej zdecydowana Oto przykład? Sekretarz stanu Tony Blinken spotkał się z ostrą ripostą chińskiego ministra spraw zagranicznych Yanga Jiechi, kiedy wypomniał Chinom tłumienie opozycji w Hongkongu, prześladowania Ujgurów i ataki na amerykańskie systemy komputerowe. Ameryka nie będzie nas pouczać, oświadczył minister Yang Jiechi, bo sama ma problem z demokracją. Dodał też, że Amerykanie nie mogą Chinom rozkazywać, bo te są

2 M. Lubina, A. Brona, Wilcza dyplomacja, „Polityka” 2021, nr 6, s. 48-49. 
suwerennym mocarstwem. Powyższe należy uwzględnić w kalkulacjach dotyczących bezpieczeństwa globalnego świata.

Wobec uznania, że największym rywalem ChRL w jej zabiegach o stanie się kluczowym graczem międzynarodowym są Stany Zjednoczone nie może dziwić to, że starają się one zacieśniać współpracę strategiczną z Federacją Rosyjską. Stara się to wykazać autor kolejnej publikacji Mateusz Wróblewski. Prezentuje on to na przykładzie współpracy w sektorze energetycznym. Zwracam uwagę na ciekawe ustalenia dotyczące przykładowo tej współpracy w obszarze Arktyki. Konkluzja tego artykułu jest następująca: „wzajemne relacje będą ulegać ciągłemu pogłębianiu ze względu na żywotne interesy stron" po czym uzasadnia przywoływane stwierdzenie.

Chińska polityka zagraniczna kierowana jest i do innych regionów świata. Przykładowo dotyczy zainteresowania Bałkanami Zachodnimi, co jest treścią publikacji Renaty Podgórskiej. Oto konkluzja powyższych rozważań: „Politykę Chin wobec subregionu Bałkanów Zachodnich cechuje pragmatyzm, wyrażający się w działaniach zmierzających do uzyskania wpływu w regionie, a za jego pośrednictwem umożliwienie poszerzenia strefy oddziaływania na Europę".

Pozostałe publikacje zamieszczone w tym tomiku mają charakter wyraźnie przyczynkarski, co nawet wynika z przytoczonych ich tytułów. Nie oznacza to, że nie będą w kręgu zainteresowań Czytelników, którzy szukają w nich informacji szczegółowych w poruszanej tematyki. Dwie ostatnie publikacje wykraczają poza problematykę chińską i dotyczą pewnych spraw związanych z Indonezją i Bhutanem.

Moja ocena zawartości zarówno recenzowanego pierwszego jak i drugiego wydawnictwa jest pozytywna i to mimo zgłaszania własnych uzupełnień i opinii. Z pewnością poszerzają one wiedzę o problematyce chińskiej, niekiedy szerzej traktowaną, stanowią też przydatną lekturę zarówno dla osób specjalizujących się w niej, jak i szerszego odbiorcę. Zachęcam potencjalnych Czytelników do zapoznania się z tymi publikacjami, jak też szerzej z serią „Biblioteki Azji i Pacyfiku”.

Przechodzę do oceny trzeciej z wymienionych publikacji o tytule „Współczesne bezpieczeństwo regionu Azji i Pacyfiku. Wybrane problemy". Jej redakcją naukowa, poza tradycyjną obecnością prof. Marszałek-Kawy, zajął się tym razem Grzegorz Kinelski. Po lekturze treści tej 
książki twierdzę, że pomimo zastrzeżeni autorskiego, że podjęte zostały „Wybrane problemy”, to ich wybór został tak dokonany, że część z prezentowanych opracowań uznaję za szczególnie cenne i nowatorskie, o czym dalej.

Na treść tej książki poza tradycyjnym wstępem składają się następujące publikacje: Aleksander Olender pt. „Wyzwania oraz zagrożenia Nowego Jedwabnego Szlaku dla bezpieczeństwa globalnego"; Karol Starowicz pt. „Między wojenną retoryką a politycznym dialogiem - Donald Trump a kwestia Korei Północnej”; Adam Paweł Olechowski pt. „Modernizacja chińskich sił zbrojnych”; Rafał Ciastoń pt. „Marynarka Wojenna Chińskiej Armii Kudowo-Wyzwoleńczej - dominacja w obszarze pierwszej i drugiej linii wysp, ograniczone zdolności na wodach błękitnych"; Justyna Eska-Mikołajewska pt. "Chińska aktywność na południowym Pacyfiku z perspektywy bezpieczeństwa Australii i jej interesów w regionie"; Grzegorz Kinelski pt. „Zarządzanie bezpieczeństwem energetycznym w wykorzystaniem zarządzania projektami energetycznymi w otoczeniu gospodarki cyfrowej na linii Unia Europejska-Chiny”; Łukasz Stach pt. „Mit węglowodorowego Eldorado? Znaczenie Morza Południowochińskiego w kontekście sporów terytorialnych na tym akwenie"; Michał Lubina pt. „Przed Rohingya. Praprzyczyny konfliktu buddyjsko-muzułmańskiego w birmańskim Arakanie”; Patryk Poborski pt. „Wybrane aspekty polityki bezpieczeństwa obcokrajowców w Koreańskiej Republice Ludowo-Demokratycznej w latach 1994-2019” oraz Bogdan Chrzanowski pt. „Służby specjalne PRL i CIA podczas wojny w Wietnamie w latach 1966-1973 (wybrane przykłady)".

Wymogi wydawnicze powodują, że nie jest możliwym dokonanie merytorycznej oceny wszystkich publikacji znajdującym się $w$ tym tomie. Wobec tego uwagę skupię na - jest to może subiektywny pogląd recenzenta - dwóch autorstwa Adama Pawła Olechowskiego i Rafała Ciastonia. Uważam je bowiem za podejmujące tematykę jak dotąd słabo znaną i popularyzowaną w polskich opracowaniach. Jest to analiza potencjału i możliwości bojowych Chińskiej Armii Ludowo-Wyzwoleńczej, a ten komponent oceniam jako drugi co do ważności, po szybko pomnażanym potencjale gospodarczym ChRL, w planach przywódców tego kraju stania się najważniejszym supermocarstwem świata. O zmianach w chińskiej polityce zagranicznej zmierzających w kierunku wyka- 
zywania mocarstwowych aspiracji tego państwa pisałem już w recenzji poświęconej wydawnictwom z serii "Biblioteka Azji i Pacyfiku” z 2019 r. Koresponduje $z$ analizami Olechowskiego artykuł Ciastonia pokazujący między innymi gigantyczny rozrost możliwości bojowych Chińskiej Marynarki Wojennej.

Co uznaję za najcenniejsze w opracowaniu Adama Pawła Olechowskiego? Jest to zainicjowanie przez obecnego przywódcę tego państwa Xi Jinping, początkowo nie ujawniany jeszcze publicznie gigantyczny program modernizacji chińskiej armii. Jednocześnie dokonano radykalnych zmian w liczebności, strukturze i organizacji jej kierowniczych struktur. Zlikwidowano jej naczelne dowództwo, w tym Sztab Generalny. Całkowicie podporządkowano ją nadzorowi politycznemu. Na jej czele stoi Komisja Bezpieczeństwa Narodowego osobiście kierowana przez Xi Jinpinga (sekretarz generalny KPCh i jednocześnie przewodniczący ChRL). Kolejnym etapem było przyjęcie 1 lipca 2015 r. nowej ustawy o bezpieczeństwie narodowym (w jego ramach mieściło się nie tylko bezpieczeństwo militarne, ale też polityka zagraniczna, kwestie ekonomiczne a nawet pewny segment kultury). Utworzono także jeden, scentralizowany system bezpieczeństwa.

Reforma Chińskiej Armii Ludowo-Wyzwoleńczej obejmowała zarówno jej zmiany strukturalne - o nich obszernie pisze Olechowski - jak też redukcję wojsk o 300 tys., ale przy radykalnej jej modernizacji technicznej, co także można znaleźć w przywoływanym opracowaniu. Proces ten trwa z jego coraz większą dynamiką. Z pewnością bez uwzględnienia szczegółowych danych zaprezentowanych w recenzowanym opracowaniu trudno rozpatrywać mocarstwowe aspiracje ChRL.

Treść przywoływanego artykułu postanowiłem uzupełnić też o pewne własne badania mogące uszczegółowić strategię wojskową tego państwa.

Wyrazem nowego podejścia nie tylko teoretyków, ale i polityków oraz wojskowych ChRL może być opublikowana w 2008 r. „Polityka Bezpieczeństwa Narodowego Chińskiej Republiki Ludowej”. Dla armii postawiono cel „być zdolną do prowadzenia wojny i jej wygrania”, przystąpiono do rozwoju i modernizacji sił zbrojnych (priorytet dla lotnictwa, marynarki wojennej i wojsk rakietowych). Wojsko otrzymało większą rolę $w$ realizacji polityki zagranicznej. Z niej wynika duże zainteresowa- 
nie tego państwa przykładowo cyberbezpieczeństwem ${ }^{3}$. Z pewnością wpływ na to ma refleksja teoretyczna teoretyków chińskich. Oznaczała ona próbę podejmowania konfrontacji z globalną dominacją Stanów Zjednoczonych jako jedynego supermocarstwa.

Duże przeobrażenia zachodzące w ChRL w kwestiach globalnej polityki zagranicznej, ekonomicznej i wojskowej nastąpiły po 2012 r. wraz z przejęciem kierownictwa państwa przez Xi Jinpinga. Zdefiniowane zostały główne cele strategiczne. Co prawda nie zmieniony został ten najważniejszy „odrodzenie wielkości chińskiej nacji i potęgi państwa”, ale zmianie uległy drogi prowadzące do niego.

Kwintesencję chińskiej strategii politycznej i militarnej zawiera opublikowana w maju 2015 r. „Chińska strategia wojskowa”. Chińska polityka obronna określona została jako defensywna zaś rozbudowę swych sił zbrojnych rozpatruje jako element modernizacji państwa służący rozwojowi ekonomicznemu kraju. Podkreślona została nie agresywność chińskiej strategii bezpieczeństwa państwa i zasada nie uciekania się jako strona pierwsza do użycia broni jądrowej. Zastrzeżono jednak prawo do przeprowadzenia wyprzedzającego ataku jądrowego w wypadku nieskuteczności ostrzeżeń potencjalnego agresora. W doktrynie tego państwa znajduje się zapis o woli zdecydowanej ochrony zjednoczenia ojczyzny i zapewnienie bezpieczeństwa interesów tego państwa w „nowych domenach". Jest to zastrzeżenie sobie prawa do zabiegów o wchłonięcie Tajwanu i ochronę trudnych do zdefiniowania interesów narodowych. Może to oznaczać przykładowo podjęcie starań o dominującą pozycję na morzach okalających to państwo, a może i oceanach.

Prezydent Xi Jinping obiecał - nie było to ujawniane, że uczyni z Chin potęgę militarną i zobowiązał się do dokończenia modernizacji sił zbrojnych do 2035 r. oraz zbudowania wojska na światowym poziomie, które będzie w stanie wygrywać wszystkie wojny na wszystkich teatrach do 2050 roku. Za deklaracjami szły czyny. W 2020 r. wydatki ChRL na siły zbrojne wyniosły 6,6\% PKB, w kolejnym mają wzrosnąć do 6,8\%. Na początku 2021 r. w czasie obrad Centralnej Komisji Wojskowej, której prze-

3 P. Borkowski, Koncepcje cyberbezpieczeństwa w ujęciu Chińskiej Republiki Ludowej - wybrane aspekty, „Przegląd Bezpieczeństwa Wewnętrznego” 2015, nr 15(7), s. 49-59.

4 S. Zarychta, Broń jądrowa w kształtowaniu bezpieczeństwa 1945-2015, Warszawa 2016, s. 501. 
wodniczył Xi Jinping, dwaj wpływowi generałowie stwierdzili, że ChRL musi się przygotować na tzw. „pułapkę Tukidydesa” ${ }^{5}$. Pojęcie to opisuje sytuację nieuchronnego konfliktu pomiędzy „wschodzącym” a „dominującym" mocarstwem. I tak wiceszef tej Komisji gen. Xu Qiliang stwierdził, że „Najważniejsza jest wewnętrzna jedność i spójność, a także poprawa ogólnych zdolności. Jeśli jesteś silny, możesz osiągnąć długoterminową stabilność oraz niezwyciężoność" ${ }^{\circ}$. Z kolei chiński minister obrony, także członek przywoływanej Komisji, gen. Wei Fenghe stwierdził, że „powstrzymywanie i przeciwdziałanie powstrzymywaniu będzie nadawało główny ton w bilateralnych stosunkach pomiędzy Chinami a USA"7. Wei Fenghe ocenił, że "bezpieczeństwo narodowe Chin weszło w fazę wysokiego ryzyka. Zadania wobec sektora obronnego i wojskowego rosną". Jak dodał, Chiny „muszą kompleksowo wzmacniać szkolenia i gotowość do wojny, a także muszą ulepszać strategiczne zdolności do odniesienia zwycięstwa nad silnymi przeciwnikami". Powyższe uwagi stanowią rzadki ze strony ChRL przykład przyznania się, że kraj ten dostrzega rosnące ryzyko konfrontacji ze Stanami Zjednoczonymi. Stwarza to ewentualne poszerzenie konfrontacji, także z użyciem środków militarnych, z dotychczas rozpatrywanego Zachód (głównie USA) - Federacja Rosyjska, także na USA - ChRL. Do tego Pekin stawia na nowoczesne technologie oraz wizje prowadzenia wojen i teatry wojen. Stąd tak duże znaczenie przywiązywane do uznania cyberprzestrzeni za szczególnie ważny wymiar przyszłych wojen ${ }^{8}$.

Cechą charakterystyczną militarnych przygotowania ChRL do nowej przyszłej wojny globalnej jest kładzenie nacisku przede wszystkim na nowe teatry wojny i stosowanie niekonwencjonalnej broni. Postawiono

5 Pojęcia to pochodzi od starożytnego greckiego historyka Tukidydesa, który w rozprawie „Wojna Peloponeska” stwierdził, że wojna peloponeska pomiędzy „wschodzącymi Atenami” a „ustabilizowaną potęgą regionalną Sparty” była nieunikniona. Samo współczesne pojęcie „pułapki Tukidydesa” jest autorstwa Grahama Allisona, profesora Kennedy School of Government na Uniwersytecie Harvarda.

6 Chińscy generałowie mówią o „pułapce Tukidydesa”: Musimy przygotować się na możliwą konfrontację z USA, forsal, bloomberg, KN, 9.03.2021 r.

7 Ibidem.

8 A. Mitręga, Aktywność Chińskiej Armii Ludowo-Wyzwoleńczej w cyberprzestrzeni, [w:] Bezpieczeństwo w cyberprzestrzeni. Wybrane zagadnienia, red. M. Molendowska, R. Miernik, Toruń 2020, s. 72-88. 
na wykorzystanie do tego przestrzeni kosmosu oraz cyberprzestrzeni. W tej drugiem państwo to zdecydowanie znajduje się w czołówce światowej. Należy też zwrócić uwagę na stawianie na rozwój nowoczesnej broni biologicznej. Otóż z dokumentów uzyskanych przez „Daily Mail” wynika, że w 2012 r. państwo to uruchomiło ogólnokrajowy program, kierowany i finansowany przez chińską Narodową Fundację Nauk Przyrodniczych, mający na celu odkrycie nowych wirusów, identyfikację organizmów mogących zakażać ludzi, zbadanie ich ewolucji oraz poszukiwanie czynnika odpowiedzialnego za rozprzestrzenianie się chorób. W 2018 r. stwierdzono, że zespoły naukowe odkryły cztery nowe patogeny i dziesięć nowych bakterii oraz ponad 1640 nowych wirusów przy użyciu technologii metagenomiki .

Oficjalnie ChRL twierdzi o defensywności ich strategii obronnej, faktycznie stawia też na_rozwój ofensywnych środków walki. Oto jak określona została strategia bezpieczeństwa tego państwa opublikowana w ramach „Białej księgi bezpieczeństwa z 2019 roku” ${ }^{10}$. W sprawach wewnętrznych to dążenie do zachowania integralności terytorialnej, politycznej i społecznej dla osłabienia przewagi militarnej Stanów Zjednoczonych. Natomiast w polityce wojskowej sprowadza się to do dominacji militarnej na Morzu Północnochińskim, w tym w odniesieniu do Tajwanu oraz wysp położonych na tym akwenie morskim. Dążenie do dominacji powietrznej w regionie. Cel to stanie się supermocarstwem w XXI w.

Jak już wcześniej sygnalizowałem wysoką ocenę wystawiam także opracowaniu Rafała Ciastonia o potencjale Marynarki Wojennej chińskiej armii, której przywódcy tego kraju wyznaczyli realizację celów politycznych w szczególnie dla nich ważnym obszarze akwenów morskich morza: Żółtego, Wschodnio- i Południowochińskiego. W przywoływanym opracowaniu Czytelnik znajdzie interesujące dane o potencjalne chińskiej marynarki wojennej, w tym jej lotnictwie morskim, uzbrojeniu m.in. w pociski balistyczne oraz inne szczegółowe informacje. Częściowo z tą problematyką koresponduje też artykuł Justyny Eska-Mikołajewskiej.

9 Chiny przygotowywały się do wojny opartej na broni biologicznej? Media dotarły do dokumentów pap, jbt, 9.05.2021.

10 P.P. Paszek, Strategia bezpieczeństwa Chińskiej Republiki Ludowej w świetle białej księgi bezpieczeństwa z 2019 roku, „Bellona” 2020, nr 1, s. 49-64. 
Zachęcam potencjalnych Czytelników także do zapoznania się z pozostałymi opracowaniami niekiedy mającymi wymiar podejmowania tematyki nie tak nośnej jak w wypadku tych nieco szerzej zaprezentowanych.

Mam nadzieję, że kolejne wydawnictwa z przywoływanej „Biblioteki Azji i Pacyfiku" będą kontynuacją poprzedników i, że seria mieszcząca stanie się najpopularniejszą we współczesnej polskiej historiografii. Stąd apel do Pani Prof. Marszałek-Kawy aby zachęcała do uczestnictwa w niej jeszcze szerszej plejady autorów. Apel ten kierować można i do autorów spoza Polski.

\section{Bibliografia}

Bodio, T., Marszałek-Kawa, J. (red.) (2020), Z badań nad historią i współczesnością Rosji, Azji Centralnej i Kaukazu. Toruń, Wydawnictwo Adam Marszałek, ss. 270.

Borkowski, P. (2015), Koncepcje cyberbezpieczeństwa w ujęciu Chińskiej Republiki Ludowej - wybrane aspekty, „Przegląd Bezpieczeństwa Wewnętrznego", 15(7), s. 49-59.

Lubina, M., Brona, A. (2021), Wilcza dyplomacja. Polityka 6, s. 48-49. Marszałek-Kawa, J., Zamasz, K. (red.) (2020), Chiny z perspektywy XXI wieku. Toruń, Wydawnictwo Adam Marszałek, ss. 220.

Marszałek-Kawa, J., Kinelski, G. (red.) (2020), Współczesne bezpieczeństwo regionu Azji i Pacyfiku. Wybrane problemy, Toruń, Wydawnictwo Adam Marszałek, ss. 244.

Mitręga, A. (2020), Aktywność Chińskiej Armii Ludowo-Wyzwoleńczej w cyberprzestrzeni, [w:] Bezpieczeństwo w cyberprzestrzeni. Wybrane zagadnienia, red. M. Molendowska, R. Miernik, Toruń, ss. 72-88.

Paszek, P. (2020), Strategia bezpieczeństwa Chińskiej Republiki Ludowej w świetle białej księgi bezpieczeństwa z 2019 roku, Bellona 1, ss. 49-64. Zarychta, S. (2016), Broń jądrowa w kształtowaniu bezpieczeństwa 1945-2015. Warszawa. 